\title{
The Impact of Knowledge-based Economy on The Development of The Innovation in Services: Case of Algerian Banks and Insurance Companies
}

\author{
Cherchem Mohamed
}

Laboratory LAMEOR, University of Oran, Algeria

\begin{abstract}
According to the literature that exists on the contents of the Knowledge Based-Economy (KBE), concept approaches you through different themes distinguished as: knowledge and information, cooperation and coordination of public and private actors and KBE, human resources and $\mathrm{KBE}$, Technology Information and Communication in the knowledge economy and innovation in services. We found that innovation and service are the pillars for the development of KBE. Indicators of the knowledge economy are most frequently the manufacturing industry. The role of services in the innovation process has been long regarded as secondary. Yet innovation is affecting more and more service activities.

The objective of this work is to link these two issues by focusing on the issue of innovation in services and The KBE. An empirical study allows us to evaluate and estimate the perceptions of banks and insurance Algerian public to the concept of the KBE and innovation as well as responsible attitudes towards new products and services and The KBE. This paper works to shed light on this issue.
\end{abstract}

Keywords: knowledge-based economy (KBE), innovation, services

\section{Introduction}

"... To make knowledge workers productive will be the main challenge of the next hundred years, such as making workers productive textbooks was that of the last hundred." Peter Drucker.

The Taylor's organization founded on the principle that a human hand is now replaced by another approach, that man is a brain, a human capital. Indeed, the contemporary organization is experiencing profound changes; it evolves in an economy based on knowledge: a source of creativity and innovation. Investments in the creation and sharing of knowledge $(R \& D$, training, education ...) are rising sharply, Peter Drucker has identified knowledge as a new criterion of competitiveness in society post builds "...the productivity of knowledge is going to become for a country, an industry, or a company, the determing
competitiveness factor... ».

The objective of this work is to articulate the problematic of The KBE and the question of innovation in services. These two problematics have evolved in such a dependent and similar way. Knowledge and innovation are strongly linked with each other, one causes the other. Our research was initially thought organized around these questions: how can KBE develop the capacity of innovation in services? And how can it meet the challenges of competitiveness? Thus, our problem is about understanding the impact of KBE on the development of the capacity of innovation in services. We chose the empirical case study in the field of Banking and Insurance Algerian. We will present the research design that allowed us to study this problematic.

Copyright (C) 2011 Cherchem Mohamed. This is an open access article distributed under the Creative Commons Attribution License unported 3.0, which permits unrestricted use, distribution, and reproduction in any medium, provided that original work is properly cited. Contact author: Cherchem Mohamed, e-mail: mcherchem@yahoo.fr 
To discuss this issue, three objectives were highlighted:

1. Analyze the theories of the $\mathrm{KBE}$ and innovation in services.

2. Show the link between the $\mathrm{KBE}$ and innovation in services.

3. Highlight the role of communities of practice in the creation and transfer of innovative knowledge, particularly in the development of innovative capacity.

Our paper consists of two parts. The first part is a literature review, carried out on the $\mathrm{KBE}$ and innovation in services. The second part is a phase of access to reality in which we will analyze the empirical data and reveal the results.

\section{Review of the Literature}

\section{The Major Precursors of the KBE}

Hayek, Machlup and Simon, three great precursors of the economy of knowledge (Foray 2000), the first great modern writers of general knowledge (that is to say, not confined to science and technology) are undoubtedly Hayek, Machlup and Simon "(Foray 2000), we shall briefly discuss the work of these three economists.

Hayek addresses the problematic of knowledge in two articles that are now standard texts: "Economics and Knowledge", published in 1937 and "The Use of Knowledge in Society," published in 1945. Hayek addresses specifically the problem of the emergence of a rational economic order in a situation where individuals have only "knowledge of fragmented knowledge, incomplete and frequently contradictory. In these articles Hayek argues that the economic problem of society is more resource allocation data, but one of the rapid adaptation to changes in the particular circumstances of time and place "(Ravix and Quéré 1997).

Simon can be regarded as the true pioneer of the economy of technology and information. His research led him to develop many themes of the knowledge economy, such as the role of memorization in the learning process. Machlup (1984), meanwhile, has developed an extremely broad conception of the knowledge economy in particular covering the information economy (Machlup 1984). This broad approach has led to integration in the field of knowledge economy, not only the analysis of sectors and industries of information, but also in all economic sectors including the sectors of low knowledge intensity.

Some work done in the years ninety by Eliasson, Lundvall and Foray, which were taken by many researchers in economics, is also a significant new stage in the consideration of knowledge by economists. Eliasson believes that the tasks of production of knowledge and information processing are located in all economic activities, including low-technology sectors. This approach is different from the tradition of Machlup who had developed a specialized area. Lundvall's work goes even further. After discussing the theme of innovation systems (Lundvall 1992), he develops a reflection on the economic importance of knowledge. Lundvall conceptualized "learning", as a process that involves "the creation of new knowledge or the combination of old knowledge and the processes that bring the ancient knowledge in new faces" (Lundvall 1992). In 1994, Lundvall defends the idea of the existence of a knowledge-based economy and asserts that "knowledge is the fundamental resource in our contemporary economy and learning the most important process" (Lundvall and Johnson1994).

Several studies that have given the characteristics and definition of the KBE (Foray and Lundvall 1994), Foray provides a definition of the KBE. The current economy is the result of two "long-term trends" that are increasing the resources devoted to production and transmission of knowledge the advent of new information technologies and communication and the development of services sector.

The knowledge economy can be defined as the area of production and service 
activities which are intensive in knowledge, that is to say, fundamentally oriented innovation to continually offer new products and services worldwide (Lundvall and Foray 1994).

\section{Innovation and Services:}

The indicators of knowledge economy have been most often concerned with the manufacturing industry because of the role of services in innovation processes that has been long regarded as secondary. It appears, however, that innovation is increasingly service activities (Hauknes et al. 1998, ANRT 1999, PMB 1999).

On one hand, the diffusion of ICT is revolutionizing the production and delivery of services and offering many opportunities to create new products. On the other hand, some services appear to be determinant in the innovation activities of manufacturing firms.

These services, called KIBS (Knowledge Intensive Business Services) have increased mainly because of the outsourcing of certain manufacturing activities. Finally, the services share in total R\&D spending increased significantly, it increased by $5 \%$ across the OECD area in 1980 and over 15\% in 1995 (OECD 2000), and by their enormous contribution to employment and value-added service sectors that have a majority in the economies of developed countries, they now represent almost $70 \%$ of gross domestic product (GDP) and employment in all developed countries (OECD). The services they now represent are nearly $70 \%$ of gross domestic product and employment in all developed countries (OECD).

In the United States, 7 / 10 in France or the United Kingdom, more than $6 / 10$ in Germany and Japan are in services (OECD). Besides, several researchers, experts, measure the level of economic development according to the importance of the tertiary sector.

According to OECD services, which include the consultancy sector and professional, scientific, and financial services are considered critical services in the new economy. Because they provide, with information and support, increased productivity and efficiency of enterprises in all industries based on knowledge.

The KIS (knowledge-intensive services) meet a number of service activities' characteristic is which knowledge is both their main input and output (Miles 1994; Gallouj 2002; Toivonen 2006). They bring together many activities of the board and engineering and other activities such as financial services and insurance activities are among the most innovative by themselves, as indicated by the data CI3 (Third European Survey on Innovation).

Through this vision, the services have recently been perceived as somewhat innovative: the overall picture since they were little $\mathrm{R}$ \&amp; D and merely incorporate the technology produced upstream by the manufacturing sector (Frascati Manual) Although recognized today as the engine of economic growth and job creation in all industrialized countries, services have been surveys that helped break the image of refractory services for innovation by clearly demonstrating that services innovate, but often in other forms as in the manufacturing sector (Oslo Manual and CIS3). It took until the late 90s to see the first work-essentially qualitative experimental investigation that has been specifically designed to better understand the specificity of the innovation in the services sector. Inspired by both the Oslo Manual and Euro stat and CIS3 and more theoretical work, these investigations have provided rich results of lessons on the characteristics of innovation in the services sector. Overall, these results have significant break with the image of services insensitive to innovation, and we will show that the innovative services are often innovate in other ways than in industrial sectors and we will mention the following characteristics of innovation :

- Innovation is generally of the same intensity as in the industrial sector; 
- A significant percentage of innovations not based on any technology;

- Organizational innovation plays a very important role;

- Innovation through all phases of production is not concentrated only on the design stage;

- Innovation is rarely formally organized R\&D unit;

- Customers, the sales force and suppliers are among the main sources of innovation;

- Innovation is often intangible and therefore difficult to protect;

What is innovation in services? The answer, or rather the answers to this question vary greatly depending on the views adopted. First, conceptually, it is generally acknowledged that innovation in services is to be confused with their main characteristics:

The result of the innovation is "intangible": Given the intangible nature of services, innovation does not materialize it into a product easy to store. In most cases, the "product" of innovation is intangible, is a new idea for a new approach, a new method for introducing a new service on the market or to improve substantially the existing ones.

The innovation process is "relational": In several services, the user is linked directly to the producer in the innovation process. Innovation appears to be a mutual learning process, often simultaneously, or the provider is constantly adapting to the client's response.

The innovation process and its results are "individualized" because there are usually "co-production" between the provider and the customer. Innovation in services is more personalized and individualized than in manufacturing. The character "relational" and the heterogeneity of services are reflected in the innovation process and often become a "custom" adopted to meet the specific requirements of the customer. Finally, we conclude in the service sector that the "product" of innovation is generally intangible and nontechnological. The service innovation occurs most often in the form of a new idea, a new feature, a new approach or method. According to the statement we note that certain technical innovation in services is closely related to some aspects of the KBE.

\section{Methodology of the Research}

\section{The Research Objective}

In our case we try to analyze the conditions for successful practices of KBE and financial innovations and analyze their degree of application in the Algerian commercial banks and explore the perceptions of bankers and insurance Algerian public to the concept of $\mathrm{KBE}$ and financial innovation.

\section{The Problematic}

Are there any innovations in products and banking and insurance?

To be allowed to give an answer to this problematic and particularly corroborate our hypotheses, we put forward two hypotheses to be seen:

H1: a knowledge-based economy presents a source of development of innovation capacity particularly in financial services.

H2: The informal interaction of employees in the community of practice is a source of innovative knowledge creation. That is the purpose of our research and these are the questions we try to provide some answers for.

We adopt a research methodology based on a survey of 10 heads of state banks and public insurance company (regional directors) at Oran and the surrounding area. To carry out these investigations, we developed a questionnaire that collects information necessary to verify our hypotheses and research to solve our problem. We used the questionnaire by direct interview with each semi responsible bank. We have found this 
method more appropriate and effective in this case, given the small size of the sample and the opportunity to benefit from direct contact with bank officials chosen.

To justify the methodology, we choose to conduct the empirical study by the method of semi-structured interviews. It is capable of meeting our objectives mentioned before in a short time (considering the time of delivery of work). It also allows us to understand, deepen and test the causal relationship between the SCF and the capacity of innovation products / processes in services. The small number of companies targeted was also a reason why we will use the semi-structured interviews. For our study is consistent with the principles of the semi-directive interview, we will proceed as:

1. Make a proof of unconditional positive attention vis-à-vis the interviewee, giving importance to what he says, but also to what he hesitates to say.

2. Demonstrate an empathic attitude to perceive and understand the framework of the interviewee.

3. Restart the discussion on the important points.

And the objective of the research in our case is to analyze the methodology and to measure the perception of banks and insurance companies interviewed in the SCF and innovation and to analyze their degree of implementation in banks and Algerian public insurance.

Indeed, we will study the perceptions of banks and insurance Algerian public to the concept of the KBE and innovation; as well as the attitude of officials towards the new products and services and the KBE.

Elaboration of the questionnaire: In our study, we chose to conduct a questionnaire to be addressed to officials of commercial banks and Algerian public insurance (regional director) which are 10 chosen by the following method:
- The National Bank of Algeria (BNA).

- Le crédit Populaire d'Algérie (CPA).

- Popular Credit of Algeria (BEA).

- The Bank of Agriculture and Rural Development (BADR).

- The Bank of developments Local (BDL).

- The National Savings Fund and Provident Bank (CNEP Bank).

- Algerian Company of Transport Insurance (CAAT).

- The Algerian Company of Insurance and Reinsurance (CAAR).

- Algerian Insurance Company (SAA).

- Company of Reinsurance and Mutual Agricultural (CRMA).

These different banks and public insurance mentioned above will be the subject of our empirical research and the sample is selected from the banking and insurance market in Algeria, knowing that there are other stakeholders (including banks and foreign private insurance), as the Baraka Bank, Societe Generale, Credit Paribas, Natexis Bank, the Housing Bank, trust, 2A, Wafaa insurance products offering new banking and insurance. The reason that foreign banks have not been addressed in our investigation is that they do not have a major influence on the results of our research and for reasons of choices made early in our research.

The purpose of this empirical study is to present the analysis of results and see if they corroborate the hypotheses of our research. Then we will present the BKE practices. We present the sources of acquisition of knowledge and the role of NTIC in the KBE; after that the causal relationship between BKE and innovative capacity. Then we mention the brakes on development of the KBE and innovation and we conclude this study by mentioning the comments of the firms surveyed. 
Results

\section{Summary of Analysis of the Questionnaire:}

- Most companies are spontaneously practical methods of acquiring and transforming knowledge without knowing.

- It was noted that although the concept of the BKE in business is important, these latter may not include the terms and concepts.

- No officials of the institutions surveyed had an advanced technical definition referring to the pillars for the development of the KBE. This shows and proves the passive attitude of officials of the institutions surveyed and the narrowness of their states of mind in the KBE.

- Almost all officials interviewed, watched KBE practices in the use of computer tools and the purchase of computer equipment and training of staff in different discipline (Computer accounting, legal and finance), Some officials cited didn't have training about the practices of NTIC.

- Almost all heads of institutions surveyed use neither the Internet nor intranet and extranet in their structures and services or with their customers

- No means used for capitalisation of experience and expertise of seniors before they retire or go practice in foreign companies after their retirement.

- When a young employee is hired, he should normally follow a path of integration: that is to see the different areas and meet key people in each department; such courses are not among the institutions surveyed.

- The majority of institutions have a policy that promotes training courses but practically for seniors.
- All the seniors virtually do not capitalize their tacit knowledge of the work, consulting, publications and comments.

- No facility has asked for contacts with other research units and particularly with university researchers. These contacts are intended to enhance the knowledge, solve problems and develop the innovation process.

- The majority of banks and Algerian public insurance respondents consider that the creation and launching of new products and services are very important for the development of their institutions.

- The main reason that prevents banks and public insurance from innovating is the rigidity in their institutions and regulations in force, and factors "fear of failure and risk of innovation" this is considered the first main reason hindering the efforts of banks and insurance companies to innovate.

- The majority of banks and Algerian public insurance did not have an organizational structure that promotes the success of new products and services.

- According to the analysis, we have noticed that banks and insurance companies interviewed consider that the response to a public need is among the main factors motivating banks to innovate, so they are making no effort and not using any effective means to detect and identify these needs. Even worse, they do not consider customers as the main source for ideas and new products and services.

- No bank and insurance interviewee realizes continuous and extensive studies on the behaviour of bank customers.

- The phenomenon of imitation and copying is widespread innovations in banking and insurance, and the fact that the reaction to a new competitive product is mentioned by stakeholders 
as an important factor in relation to the needs of customers, demonstrates and proves, on one hand, the passivity of the Algerian public banks and insurance in innovation. This bad attitude is harmful for the development and success of their innovation strategies.

- All banks and Algerian public insurance are unable to assess the cost. In addition, no bank and insurance have a system of controlling and monitoring its new products and the worse is that the majority of managers interviewed do not even remember the date of launching of their new products.

- The cell R \& D and customers occupy the penultimate place as a source of ideas for new products while competitors and internal sources occupy all top positions.

- During our interviews with regional directors we have found that training of staff unfortunately remains often too technical (accounting and finance).

- The majority of banks and insurance companies we interviewed have problems with coordination and cooperation between different branches and departments "information does not flow in time".

- The majority of banks and Algerian public insurance respondents have no procedure for creating and marketing new products and services.

- The direct marketing techniques in general, and mailing (e-mailing the contact via Internet with customers and among staff) in particular, are virtually nonexistent among banks and insurance Algerian public; especially with the evolution and the growth of the technology of information and communication (NTIC) market in Algeria.

\section{Conclusion}

The KBE is not a fad. It is not just a combination of structured knowledge and information. The $\mathrm{KBE}$ is an economical system, value creative, sensitive to interactions between these pillars, such as NTIC, human resources, innovation and service, and a culture that promotes this interaction. It allows companies to use their knowledge and skills to make sustained and competitive advantages to develop its innovation capacity. As Porter states, "Knowledge and innovation are the building blocks of sustainable competitive advantage."

According to the statement, KBE persist that economies or services are the main sources of wealth and jobs. The services will increasingly come to play an important role in the development of KBE static, but it's also dynamic, that is to say, through innovation they produce or induce. (Gallouj; Djellal 2000) Knowledge and innovation are strongly linked with each other, one causes the other. In the end, there is a certain relationship between the growth of service sector and KBE.

\section{References}

Barreyre.P.Y, (1975). Stratégie d'innovation dans les PMI, Ed T\&H,

Booz, Allen \& Hamilton (1982). "Nex Product Management for the 1980's," New York,

Catin M., Guilhon B. \& Le Bas C. (2001). Activités Technologiques, Connaissances et Organisation, L'Harmattan, Paris.

Catin M., Guilhon B. \& Le Bas C. (2003). "Articulation des Connaissances tacites et Codifiées, Apprentissage et Croissance," Économies et Sociétés, série W, $\mathrm{n}^{\circ} 7$,

Caudamine, G. \& J. Montier, (1998) Banque et Marché Financiers, Ed Economica, 
Chanal, V. 'Management des Connaissances et Innovation : De Nouveaux Enjeux pour les Systèmes d'information,' p.270. In Caron Fasan, Lesca, N., "Présent et futur des systèmes d'information," PUG, 2003.

Cherchem, N. 'L'impact du Knowledge Management sur d'innovation : Essaie d'analyse sur les Unités R\&D,' Mémoire de Master Recherche Mention Management des Ressources, Humaines Année 2005/2006 Université de Rennes 1.

Cohen, E. \& P. Aghion, (2004). Education et Croissance, rapport $d u$ conseil d'analyse économique.

Crance, Ph. (2001). Le Marketing de L'innovation des outils pour Valoriser la Recherche et les Technologies Nouvelles, Revue Française du Marketing $\mathrm{N}^{\circ}$ 182/.

Djellal, F. \& Galloudj, F. (2001). L'organisation du Processus d'innovation dans les Services : les Résultats d'une Enquête Postale, Education \& Formation $\mathrm{N}^{\circ}$ 59 Avril- Juin 2001.

Djellal, F. \& Gallouj, F. (2009).."Innovation Dans Les Services Et Entrepreneuriat : AuDelà Des Conceptions Industrialistes et Technologistes du Développement Durable" Cahiers d'économie de l'innovation (eds) de boeck n²9, PP. 59-86.

Dominique Foray, (2006). La Suisse dans l'économie de la Connaissance Septembre. http://cemi.epfl.ch

Drucker, P. (1993). "Au-delà du Capitalisme, la Métamorphose de cette Fin de Siècle," Dunod.

Drucker,P : Voulez-vous innover? , Harvard expansion, Hiver 1985-1986.

Durand,R la vraie valeur de l'innovation, L'Expansion Management Review $\mathrm{N}^{\circ} 71$ Juin 2003.

Duvinage, F. (2003). "Economie basée sur la Connaissance et Gouvernance Territoriale de la Connaissance," Doctorat en science de gestion : INPL, Nancy.
Eiglier, P. \& Langeard, L. (1994). Servuction Ediscience édition Paris.

Emmanuel. Métais \& Bernard Moingeon, (2001). Management de L'innovation : le "Learning Mix," Revue française de gestion, mars-Avril.

Ferrary, M. \& Pesqueux, Y (2006). 'Management de la Connaissance : Knowledge Management, Apprentissage Organisationnel et Société de la Communication,' p. 168, Economica,

Gay, C. (2003). 'Économie de l'innovation technologique localisée: un essai sur les individus, organisations et réseaux apprenants,' Thèse Université de Lyon 2, Décembre.

Harfi,H El Mouhoub Mouhoud Et Rémi Lallement, les Indicateurs de L'economie de la Connaissance, Note d'introduction aux travaux du séminaire d'experts réuni dans le cadre de l'axe 'La France dans l'économie de la connaissance' du programme de travail du SDTI.

Ingham, M. (2001). Innovation: de L'exception à la Règle, Revue Française de Gestion, $N^{\circ} 118$ /

Jallat, F. (1994). Innovation dans les Services: les Facteur de Succès, Décision Marketing, $\mathrm{N}^{\circ}$ Mai-Août - 23.

Joseph Schumpeter (1999). Capitalisme, Socialisme et démocratie, Dalloz www.plan.gouv.fr www.univ-

tlse1.fr/lerps/present/present/vicent;html

Killeya et Armistead (1991). cité dans J. Nollet et J. Haywood-Farmer, les entreprises de services,Gaetan Morin Editeur, 1992.

Landry, R., Lamari, M. \& Amara, N. (2001). "Apprentissage et Innovation : une Analyse Économétrique à partir de Données d'enquêtes dans les Entreprises des Régions de Québec et de Chaudière Appalaches," Université de Laval, Québec, Canada. 
Lévy,M Jouyet,J. P. (2006). L'économie de l'immatériel La Croissance de Demain, L'économie de l'immatériel La Croissance de Demain Rapport de la commission sur l'économie de l'immatériel mars.

Libmann, F. (1982). Méthode pour Innover et se Diversifier, les Editions d'organisation,

Marian, M. (1999). 'Le Boom des Services Stratégique aux Enterprises,' dans l'observatoire de L'OCDE, decembre1999.

MEN- Direction de la programmation et de développement, Décembre 2002

Ministère jeunesse éducation recherche (France). La recherche développement dans les services en quête de mesure, Note recherche03.02 Octobre.

Moles, A. \& R. Claude, (1970). Créativité et Méthodes d'innovation dans l'entreprises, Ed Fayard Mame,

Morin, P. (1989). 'Réponses au Refus du Produit Nouveau,' Revue Française de gestion, Janvier, Février.

Morton.J, (1969). le nouveau produit, Ed Dunod.

OCDE (1999). 'Forum de la Politique de l'entreprise et de l'industrie sur l'économie des Services,'

OCDE. (2004). Société du Savoir et Gestion des Connaissances - Enseignement et Compétences. Paris.

OCDE (2006). "Actifs Immatériels et
Création de Valeur," réunion du conseil de l'OCDE au niveau ministériel.

Paillard, S. Les indicateurs de l'économie de la connaissance, Commissariat General Du Plan Service du Développement Technologique et Industriel Document de travail.

Pierre Berot, Pascale Piérti- Bessy, division services, INSEE Les entreprises de services innovent aussi $\mathrm{N}^{\circ} 982$ Août 2004.

Prax, J.Y. (2003). “Le Manuel du Knowledge Management: Une Approche de Deuxième Génération," p. 423, Dunod.

Quéré, M. et J.-L. Ravix. (1997). 'Le chercheur entrepreneur dans la dynamique des relations science-industrie: un cadre d'analyse,' Economie de la Connaissance et Organisations. Paris, L'Harmattan.

Réal, J. (2000). 'Gérer les Connaissances : Un Défi de la Nouvelle Compétitivité du 21e Siècle, Information, Interaction, Innovation,' Etude de Recherche CEFRIO et l'Université du Québec à Trois Rivières, p. 41 Octobre. In www.cefrio.qc.ca

Rigny, L. (1973). 'Sructure de l'entreprise et Capacité d'innovation,' Ed. H\&T.

Roberston, T. (1967). "The Process of Innovation and the Diffusin of Innovation," Journal of Marketing volume 31, Javier.

SESSI (1999). 'l'innovation dans les Services aux Enterprises,' Nํ105 Mars.

Zollinger, Z. (1992). Marketing et Stratégies Bancaires, Ed Dunod. 